\title{
Mobile advergame: analysis of flow, attitudes and competitor trait as the moderating variable
}

\author{
Sri Hartini \\ Faculty of Economic and Business, \\ Universitas Airlangga, \\ Surabaya, Indonesia \\ Email: hartini_unair@yahoo.com
}

\begin{abstract}
The focus of this study will be on mobile advergame as the communication media of online marketing. Mobile advergame is a video game which in some ways it contains an advertisement for a product, a service or a company. This study examines the relationships of consumer flow, attitude towards mobile advergame, attitude towards brand and consumer characteristics, especially competitor trait as the moderating variable. This study used quantitative approach with hypothetical analysis. To collect the data, this study used purposive sampling method. Six mobile advergames, especially adventure genre were used in this study. A total of 162 game players as participants were involved in the survey. The participants were obtained when they were playing the mobiles advergame. The result shows that consumer flow influences the attitude towards mobile advergame and competitor trait moderates the relationships. Attitude towards mobile advergame influences attitude towards brand. Consumer flow does not influence attitude towards brand and competitor trait does not moderate relationship flow on attitudes towards brand.
\end{abstract}

Keywords: flow; attitude; competitor trait; mobile advergame.

Reference to this paper should be made as follows: Hartini, S. (2020) 'Mobile advergame: analysis of flow, attitudes, and competitor trait as the moderating variable', Int. J. Mobile Learning and Organisation, Vol. 14, No. 3, pp.322-337.

Biographical notes: Sri Hartini is a Lecturer at Economic and Business Airlangga University, Surabaya, Indonesia. She graduated from the Management Doctoral Program, Airlangga University. She is interested in marketing strategic, consumer behaviour and creative industry.

This paper is a revised and expanded version of a paper entitled 'Advergame: Analysis of Flow, Attitude and Competitor Traits as Moderator' presented at the 'JBFEM Award \& Symposium 2018', Shaw Foundation Alumni House in National University of Singapore (NUS), 2-3 August 2018.

\section{Introduction}

The increasing number of internet users has indicating a fast growing technology, especially internet. Internet has opened a window of the world that gives a new platform in running a cyber-market business as well as to connect people around the world. The internet makes everyone easy to interact without restriction with others who are in 
other parts of the world that are extremely far away easily, fast and cheap. It is also acknowledged that internet successfully gives impacts on business competition. It makes that the companies face a new challenge due to a better access had by consumers in getting the information. This fact should be considered by the marketers. Many companies are drawing up their strategy into an online marketing strategy since it has many advantages. For instance, the companies can directly deal with the targeted market. It also enables the companies to get a valid information from the sources. Therefore, the distribution costs are possibly reduced, in which leading to the more efficient marketing costs.

Mobile advergame is one of the marketing strategy media. It used to be only as a game for children and as an entertainment media for adult. As technology developed and human needs more varied, nowadays the game has being developed, even though it remains interactive and still as a medium of entertainment. One of benefits of the game which is much developed from its origin is that the game is considered as a medium of learning and training. Moreover, game also becomes a medium of campaign which is known as mobile advergame. Mobile advergame can be as a promoting tool because of its interactive multimedia. This interactive ability makes mobile advergame far beyond the previous promoting media. In a game, there are two-way communication and dynamic changes during the process between the user and the media. It makes a game becoming a dynamical media and very promising, because it can be designed in such a way that is intended for more optimum interaction according to specific needs. Game offers a freedom to act and getting feedback immediately. Moreover, game has high dynamics; this makes game loved and even it is considered effective to be used as a learning media for school, children and company level.

How mobile advergame is used in the company, at the beginning, is by embedding the brand in the game. Promotions are still just patches, which is simply installing a logo or product brand in the game's opening screen. Game creates a very conducive environment for brand promotion. Now, business people are starting to realise that they can insert their own brand or product in the game as one of the interactive promotional tools (Laskowska-Witek and Mitręga, 2014; Aggarwal and Arora, 2019).

Businesses people begin to realise that they could incorporate both the brand and the product itself in the game as an interactive medium of promotion. Many companies try to use game as a promotional media for their own products or services (Gura and Gura, 2016). It is not just a brand, logo or products that are displayed in the game, but now the brand or product itself is used directly as the game. Game, by several global companies, has started to be used as a trial medium for products that have not been created yet. In other words, businesses can use the game as a research tool to know the needs and demands of the market users (Vashisht and Pillai, 2017).

Game can be spread through websites and becomes viral. When the game is interesting and is able to make players being addicted, brand messages will be embedded in the players' mind (Sreejesh et al., 2018). As long as the game is enjoyable, the players will not mind seeing the brand. The point is how to make the game interesting, but it still can embed the brand message in the players' mind.

The purpose of mobile advergame is the same as other forms of advertising the creation of target market's positive attitude including the cognitive, affective and conative aspects towards the products. Attitude towards the product or brand is started from the attitude on the mobile advergame itself. When a person likes the mobile advergame played, he will love the product offered or showed. Attitude towards mobile advergame starts from the feeling of flow on mobile advergame. Flow is a situation 
where a person is completely involved in a certain activity (Vanwesenbeeck et al., 2016). Meanwhile, flow is defined as an enjoyable experience encountered through total concentration in conducting a task (Csikszentmihalyi, 1997; Huang et al., 2018). Flow with high intensity will create a sense of love on the mobile advergame as well as the brand embedded on it. Flow becomes an important determinant in shaping the consumer attitudes (Hernandez, 2011) especially among gamers (Hopp and Barker, 2016).

The higher flow experienced, which means the higher an individuals' involvement in the game, the more positive their attitude towards the mobile advergame. Moreover, the higher the intensity of flow, which means the more often they are related to the existing brands on the mobile advergame, the more positive their attitude towards the brand exposed on the mobile advergame.

Subliminal message is a hidden message that is inserted on particular objects or media, such as message on mobile advergame. This message aims to influence the subconscious mind of the target market. This message cannot be received by their conscious mind but in some situations, it can affect the subconscious to create an action or attitude. The messages, purposely, are made not very clear or remain unnoticed in the first time they are seen. These messages will be recorded in our brain and will work like hypnosis. The effects of these messages can have both positive and negative impacts depending on the hidden message delivered. This subliminal message is what they will offer through mobile advergame. Subliminal messages will work if the audience is unaware of the persuasion or intention behind the game (Sofi et al., 2018).

Regarding the decision making made by consumers, it is known a consumer's decision. Consumer's decision is a process of getting goods and services to meet the needs, including factors that influence purchasing decisions and actions that precede and follow their actions. This decision involves several internal and external factors that involve their stimuli. Each consumer is different in nature and behaviour, thus the marketers must be observant and have several different treatments in order to achieve their marketing objectives. Marketers must be creative in providing stimuli and also choose appropriate media for their marketing communications. This suitability will make the marketing messages are more easily accepted by consumers, so that it is expected to influence their behaviour and their attitude towards the brand.

Consumer's characteristic will determine their response to their environment. These characteristics include demographic, psychological and social characteristics. Related to mobile advergame, it is psychological characteristic of consumers which determine the behaviour of players. Sreejesh et al. (2018) and Vorderer and Bryant (2012) distinguish the characteristics of game players in nine types. The most common type of game players are liking challenges and competitions. The characteristics of the players will affect how the audience behaves among others, how they process information in mobile advergame, the audience's flow feelings on mobile advergame and how the audience responding to mobile advergame and brands on mobile advergame.

\section{Literature review and hypothesis}

\section{$2.1 \quad$ E-commerce and mobile advergame}

E-business is a business activity carried out by companies by utilising digital technology, and e-commerce is one of e-business manifestations (Strauss and Frost, 2016). Electronic 
Commerce (e-commerce) is not only about the problem of selling and buying products online, but also about a comprehensive online process ranging from development, marketing, sales, shipping, service and payment for goods and services transacted through internet media by consumers with the help of internet partners by business partners (Laudon and Traver, 2016; Turban et al., 2017). Consumers are starting to look for technologies that are suitable for their high mobility as a result of accessing the internet through mobile devices. This type of electronic commerce is called mobile e-commerce or many people call it $m$-commerce (Turban et al., 2018).

Mobile advergame is a one of media for promotion in online marketing. The promotion is intended to persuade potential consumers. It will produce a positive response to the brand. A positive response to the brand begins with a positive response to the advertising, if the consumers have a positive response to the advertising, it will bring a positive response to the brand (Schiffman and Kanuk, 2010). Mobile advergame is a game-based computer program dedicated to promote a brand (Cauberghe and De Pelsmacker, 2010). The mobile advergame format can be distinguished from in-game advertising in which in-game advertising is more about product placement inside the game. It means that the engagement process between the brand and the player will only be happened when the player is exposed to the product or brand itself. When the product is not well placed, most likely the player will miss it and there is no engagement process to the product or the brand on the in-game advertising (Gurau, 2008; Cauberghe and De Pelsmacker, 2010). It is different when a brand is packaged or promoted into a game format, namely mobile advergame. Mobile advergame is usually simpler when compared to the real games in which brand can be placed inside. This form of mobile advergame can actually add the engagement between the brand and the player because the player can be more familiar and experience to see the brand. Therefore, to generate an engagement between the player or consumer and the brand when advertising it, the consumer needs to have a positive feeling in the brand when they play mobile advergame (Goh and Ping, 2014).

\subsection{Flow and consumer attitude}

Flow is an individual's holistic experience in doing certain activities with condition of completely involved. Flow can be defined as a state of being immersed in an activity wherein individuals can intrinsically achieve the enjoyable conditions and lose the selfconsciousness (Csikszentmihalyi, 1990). An individual in this condition will fully concentrate on his activities; the focus is only on what he is doing and never pay attention to other things that are not related to what is being done at that time (Wu et al., 2016). Thus, he has a total control over his activities (Koufaris, 2002; Nusair and Parsa, 2011; Wu et al., 2016). It also enable to cause feeling of pleasure and comfort when an individual is in this condition, even for a long time period of time (Csikszentmihalyi, 1990; Novak et al., 2000).

Flow can explain how an individual can produce a higher performance when having a higher level of focus and full concentration in carrying out the activities (Csikszentmihalyi, 1990; Novak et al., 2000) and someone in this condition will find a self-gratification (Mathwick and Rigdon, 2004). Csikszentmihalyi (1990) claims that there are two important aspects when a person finds an experience in doing an activity, 
that is, to what extent the challenge is (challenge factor) and to what extent the ability to face the challenge (skill factor). Flow is a condition when someone has a balance between skills and challenges.

Flow is defined as a holistic experience felt by an individual while doing certain activities with conditions of total involvement, in which an individual in this condition will be immersed in his activities, he has full attention on the activity and lose the conscious thought to something around and feels total control over the environment of his activity (Novak et al., 2000; Koufaris, 2002; Wu et al., 2016). Someone who reaches the condition of flow in online activities will feel that he is united with the interface and navigation provided (Novak et al., 2000) and as a result someone who experiences this condition will feel pleasure or enjoyment in doing his activities in online media (Mathwick and Rigdon, 2004). Flow in an online context can be seen from several aspects, with the indicators of flow, including Telepresence, the level of awareness of the surrounding environmental atmosphere while focusing on exploring activities in social media applications; Time Distortion, the level of awareness of the time spent on exploring activities in social media applications; Skill, the level of ability to navigate social media applications; Challenges, the level of challenges that arise from the design and display of products on social media applications (Novak et al., 2000; Hausman and Siekpe, 2009).

Flow leads consumers to a high level of enjoyment, which has high concentration and involvement, makes the activity feel interesting and makes them sink into the activity naturally (Hu et al., 2006). The results of optimal flow will make consumers have an objective positive experience from their activities known as OCE (Online Customer Experience). Flow, which makes high involvement, influences the degree of consumers' concentration and influences the intention to make transactions (Holbrook et al., 1984).

If the challenge given by the media is easier than the skill in using it, an individual will experience boredom. In contrast, if the challenge is more difficult than the skill possessed, an individual will experience anxiety (Csikszentmihalyi, 1990; Mathwick and Rigdon, 2004; Sherry, 2004). If individuals have found a balanced flow condition, they will feel an enjoyment in carrying out the activities in the media (Csikszentmihalyi, 1990; Sherry, 2004; Weber et al., 2009). Anxiety and boredom are not positive experiences, so that someone in that position will try to return to the flow condition by increasing and balancing their abilities with the challenges they are facing (Csikszentmihalyi, 1990).

Attitude is defined as an overall evaluation that is carried out by someone (Peter and Olson, 2008, p.120). Attitude is an evaluative response which can only arise if individuals are faced with a stimulus that requires an individual reaction. Whereas Kotler and Keller (2016) define attitude as evaluation, emotional feeling and tendency of beneficial or unfavourable and long-lasting actions in a person towards certain objects or ideas. Mowen and Minor (2001, p.319) define attitudes as an affection or feeling for a stimuli. Attitude is the response of like or dislike towards an object. Attitude is usually very difficult to change. Attitude shapes the intention to buy or not to buy the products. Attitude consists of three components: the affective component, the cognitive component and the conative component (Schiffman and Kanuk, 2010).

Flow is a situation where a person involved in an activity (Hoffman and Novak, 1996). Flow with high intensity will create a sense of love on the mobile advergame and brand that exist on the mobile advergame. Hernandez (2011) in his study proved that flow becomes an important determinant in the formation of consumer attitudes. The 
higher the flows, the more involvement of people in the game and the more positive their attitude towards the mobile advergame. Regarding to the intensity of the flow, the more often they relate to the existing brand on the mobile advergame, the more positive their attitude towards the brand on the mobile advergame. The hypothesis can be formulated as follows:

\section{H1: Flow has a significant positive impact on attitude towards mobile advergame.}

H2: Flow has a significant positive impact on attitude towards brands.

Someone who has a positive attitude on an object will tend to have a positive attitude on all components or attributes of the object. Likewise related to mobile advergame, a person who has a positive attitude on mobile advergame, he will have a positive attitude on the attributes of mobile advergame, such as brands that are showed in the mobile advergame. Meanwhile, Waiguny et al. (2011), in his study, showed that the attitude towards mobile advergame will have a positive impact on attitude towards the brand or product exposed on mobile advergame.

H3: Attitude towards mobile advergame has a significant positive impact on attitude towards brands.

\subsection{Competitor trait on consumer behaviour}

Consumer's purchasing decision is a process of getting goods and services to meet the needs, including factors that influence purchasing decisions and actions that precede and follow their actions. This decision involves several internal and external factors that involve their stimuli. Each consumer is different in terms of behaviour, so that marketers must be observant and have several different treatments; thus their marketing objectives can be achieved. Stimuli sometimes are also related to how the consumer appears and needs. This is usually applied to innovative items. Marketers must be creative in providing stimuli and choose appropriate media in their marketing communications. This suitability will make marketing messages more easily accepted in the minds of consumer, so that it is expected to influence their behaviour and their attitude towards the brand.

There are many factors that can influence consumer purchasing decisions (Blackwell et al., 2006). These factors include store promotion, store atmosphere, service level, price and the entire experience that consumers get when they are in the store and these factors will differentiate between one customer and another in determining purchasing decisions (Blackwell et al., 2006; Hawkins and Mothersbaugh, 2012).

The consumer decision-making process can be viewed as three distinctions but related stages: input, process and output stage (Schiffman and Kanuk, 2010). Consumer's characteristic will determine people's response to their environment. These characteristics include demographic characteristics, psychological characteristics and social characteristics. Demographic characteristics include age, education, gender, occupation and income. Psychological characteristics include personality, learning, memory and shared values, religion and nationalism. Social characteristics are individual characters formed from the social conditions in which the individual is lived like consumer's life style. 
Associated with the mobile advergame, Vorderer and Bryant (2012) distinguished the characteristics of game players in nine types, such as competitors, explorers, collectors, achievers, jokers, directors, storytellers, performers and craftsmen. Characteristics of this audience will affect how the audience behaves among others, how they process information in the mobile advergame. Competitor trait is the most common characteristic of game players, while the most widely played game genre is adventure.

The influence of consumer flow towards attitude will be determined by competitor traits. Flow emotion perceived by the game players will increase their emotions on the mobile advergame and on the brand exposed on the mobile advergame. This influence will be stronger when the game player likes competition and challenge because the more people like challenges and competitions, the more flow emotion perceived by the game players. The hypothesis can be formulated as follows:

H4: Competitors traits strengthen flow relationship on the attitudes towards brand.

H5: Competitors traits strengthen flow relationship on the attitude towards mobile advergame.

Figure 1 Research framework

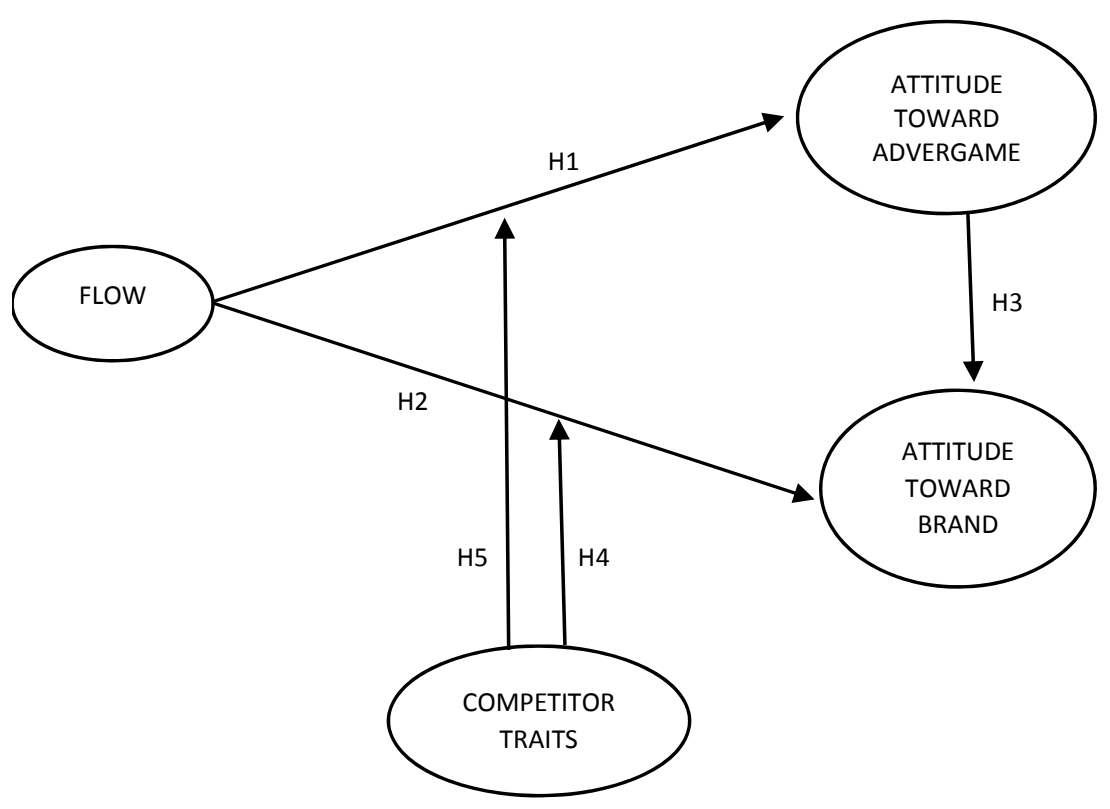

There are four variables used in this study, including flow, attitude towards mobile advergame, attitude towards brands and competitor traits. Flow as an independent variable affects two variables depending on attitude towards mobile advergame and attitude towards brand. Competitor traits variable moderates the causal relationship between flow and attitude towards mobile advergame as well as attitude towards brand. Figure 1 shows that there are five hypotheses used in this study. 


\section{Methodology}

This study aims to find the relationship among consumer flow, attitude towards mobile advergame, attitude towards brand and competitor trait. It focuses on the field of consumer behaviour, related to the promotional strategies, especially on promotional strategies through mobile advergame. Five hypothesis had been formulated. The population of this study are individuals who play a game in which there is a mobile advergame in it. The number of population is infinite because the fixed number of gamers displayed on the mobile advergame is unknown. Thereby, non-probability sampling technique, specifically purposive random sampling technique was used as the sampling method. The criteria are the individuals who play the mobile adventure game. There are six mobile advergames such as Puddle Pop Ice Cream, Pepsi mobile advergame, Giant Bom mobile advergame, Chocho Crispy mobile advergame, Chupa Chups mobile advergame and Chocapic Mania mobile advergame.

The samples taken in the present study are 200 participants, but only 162 participants samples that could be further processed due to the incomplete and inconsistent answers.

\section{Measurement}

There are four variables used in this research, that is consumer flow, attitude towards mobile advergame, attitude towards brands and competitor trait. Flow is an individual involvement in the game being played. This variable is measured by four statement items (Waiguny et al., 2012; Vanwesenbeeck et al., 2016). Attitude towards mobile advergame is the respondent evaluation towards mobile advergame played. This variable measurement is based on the emotional evaluation (Van Reijmersdal et al., 2012). This variable is measured by five question items. The questions are based on the measurement of Hernandez (2008). Attitude towards the brand is an affective evaluation on a brand in the mobile advergame (Shimps and Andrews, 2013). This variable measurement adopt the four question items developed from the measurement of Wu and Wang (2011). Competitor trait is individual characteristic of gamer who like challenges. This variable is measured by statement items developed from the research of Lu et al. (2013).

\section{Data analysis}

For analysing the data, SEM analysis with IBM Amos version 24 was used in this study. The measurement of model evaluation utilises outer model and inner model. Outer model evaluation is the evaluation of relationship between construction and indicator or its statement items. The evaluation includes convergent validity, discriminant validity and constructive relevance predictive.

Convergent validity: all AVE values in this research are above 0.5. Attitude towards mobile advergame obtained is 0.585500 and attitude towards brand is 0.512370 . The indicator is valid if it has loading factor value ranging from 0.5 to 0.6 . All indicators and dimensions in this study have loading factor value more than 0.5 . The values of attitude toward brand for its indicators are $0.723931,0.890870$ and 0.662401 , respectively.

Discriminant validity can be seen through the correlation between construct and AVE root. Al latent construct has AVE root value that is greater than the correlation among its 
latent variables. Value of attitude towards mobile advergame which has AVE root of $\sqrt{ } 0.585500$ with the value of 0.765179 ; the value is greater than the value of latent variable correlation had by other three variables: attitude towards brand is 0.355502 , competitive traits is 0.204529 and flow is 0.245047 . Reliability test is needed to measure the stability and consistency of an instrument in measuring a concept or a variable. In this study, reliability can be measured by seeing the value of composite reliability. The value of composite reliability is more than 0.70 . Based on the result of data processing, it can be known that the reliability test result in every latent variables have met the standard values, which is more than 0.70 , like the value of attitude towards mobile advergame which has composite reliability value of 0.806584 .

The evaluation of inner model or structural model is done by using $\mathrm{R}^{2}$ for dependent variables and $Q^{2}$ predictive relevance value to assess predictive relevance. $R^{2}$ value for every endogen latent variable is considered as prediction power of structural model. $Q^{2}$ value is used to know the predictive relevance had by the model. The change of $R^{2}$ value is used to explain the influence of certain exogenous latent variable towards endogenous latent variable. $R^{2}$ values of $0.75,0.50$ and 0.25 indicate the model is strong, moderate and weak. $R^{2}$ value in this research is 0.227104 for attitude towards mobile advergame variable, meaning that the influence on the change of other constructs which can be explained by attitude towards mobile advergame is $23 \%$. Thus, it can be concluded that it has weak power to moderate while the remaining is explained by other variables. Other $R^{2}$ variables also explain the same thing related to other construct changes.

Speaking about Constructive Relevance Predictive, the value of $Q^{2}>0$ reveals that the model has predictive relevance, while the value of $Q^{2}<0$ shows that the model has less predictive relevance. Based on the calculation, the value of $Q^{2}$ predictive relevance is of 0.75 . The value is greater than zero. It shows that the model has fit and strong predictive relevance, because it can explain model of $75 \%$.

Table 1 Standardised regression weights (group number 1 - default model)

\begin{tabular}{cccc}
\hline & Variables & & Estimate \\
\hline F1 & $<---$ & F & 0.768 \\
F2 & $<---$ & F & 0.479 \\
F3 & $<---$ & F & 0.222 \\
F4 & $<--$ & F & 0.401 \\
CT1 & $<---$ & CT & 0.844 \\
CT2 & $<---$ & CT & 0.624 \\
CT3 & $<---$ & CT & 0.847 \\
ATA1 & $<---$ & ATA & 0.675 \\
ATA2 & $<---$ & ATA & 1.000 \\
ATA3 & $<---$ & ATA & 0.521 \\
ATA4 & $<---$ & ATA & 1.000 \\
ATA5 & $<---$ & ATA & 0.261 \\
ATB1 & $<---$ & ATB & 0.946 \\
ATB2 & $<---$ & ATB & 0.799 \\
ATB3 & $<---$ & ATB & 0.008 \\
ATB4 & $<---$ & ATB & 0.189 \\
\hline
\end{tabular}


It can be seen from the table, the result of internal validity shows various results. According to Solimun and Rinaldo (2006), for social research, the result of validity test can be considered fit if the values of loading factor of respective indicators are same as or more than 0.3 or $(\lambda>0.3)$. In Table 1 , it can be known that the whole indicators have fulfilled criteria in which the value of loading factor must be above 0.3 or $(\lambda>0.3)$. However, there are several loading factor values which are less than $0.3(\lambda<0.3)$ which is F3 indicator $=0.222$; ATA5 $=0.261$; ATB3 $=0.008$; and ATB4 $=0.189$, so that the four indicators must be removed to make the research model fitter.

Table 2 Standardised regression weights (group number 1 - default model)

\begin{tabular}{lllc}
\hline Relationships between variables & & & Estimate \\
\hline Flow & $\rightarrow$ & Attitude towards advergame & 0.564 \\
Flow & $\rightarrow$ & Attituted towards brand & 0.345 \\
Attitude towards advergames & $\rightarrow$ & Attitude towards brand & 0.567 \\
Competitor traits & $\rightarrow$ & Attitude towards advergame & 0.621 \\
Competitor traits & $\rightarrow$ & Attitude towards brand & 0.599 \\
Competitor traits * flow & $\rightarrow$ & Attitude towards advergame & 0.671 \\
Competitor traits * flow & $\rightarrow$ & Attitude towards brand & 0.256 \\
\hline
\end{tabular}

Standardised regression weight stable reveals the external validity test which views the relation among latent variables in the research model. According to Solimun and Rinaldo (2006), for social research, the validity test result is considered fit if the value of loading factor respectively is same as or more than 0.3 or $(\lambda>0.3)$. Holistically, the relation among latent variables is based on the value of loading factor which has been above 0.3 or $(\lambda>0.3)$. However, there is only one insignificant relation which is interaction variable of Competitor traits*Flow on attitude towards brand with the value of $0.256<0.3$. Yet, this result still can be accepted because it closes to minimum value of 0.3 .

Table 3 Goodness of fit indices

\begin{tabular}{lccc}
\hline Goodness of fit index & Cut-off value & \multicolumn{2}{c}{ Result } \\
\hline$\chi^{2}$ & Expected small & 0.025 & Fit \\
\hline Significance probability & $\geq 0.05$ & 0.000 & Not fit \\
RMSEA & $\leq 0.08$ & 0.197 & Not fit \\
GFI & $\geq 0.90$ & 0.850 & Quite fit \\
AGFI & $\geq 0.90$ & 0.775 & Quite fit \\
CMIN/DF & $\leq 2.00$ & 4.829 & Not fit \\
TLI & $\geq 0.95$ & 0.920 & Quite fit \\
CFI & $\geq 0.95$ & 0.916 & Quite fit \\
\hline
\end{tabular}

Based on the table of goodness of fit indices, it shows a quite good result to evaluate the level of construct validity used. The result reveals that there is a difference between indicator result of goodness of fit such as: $\chi^{2}=0.025$ that has been extremely small and included into fit; significance probability $=0.000 \leq 0,05$ then the model is not fit; 
RMSEA $=0.197 \geq 0.08$ the model is not fit; GFI $=0.850 \leq 0.90$ quite close and the model is quite fit; AGFI $=0.775 \leq 0.90$ quite close and the model is quite fit; CMIN/DF $=4.829 \geq 2.00$ then the model is not fit; TLI $=0.920 \leq 0.95$ quite close and the model is quite fit; and finally CFI $=0.916 \leq 0.95$ quite close and the model is quite fit. Based on the aforementioned results, it can be concluded, based on construct validity, the result model has fulfilled the condition of goodness of fit. Thus, the research can be processed.

\section{Discussion}

Most of the respondents are male $(92.6 \%)$. This indicates that mostly games are played by male. The number of gamers in Indonesia is 43.7 million people, with $56 \%$ male and $44 \%$ female (LIPI, 2016). The age of male who play game is ranging from 10 to 20 years old, with the percentage: $21 \%$ is 21 to 35 years old, $26 \%$ is 35 to 50 years old of $9 \%$ and the remaining is the female player (Newzoo, 2017). This phenomenon is also supported by the data from e-marketer in 2016 stating that the percentage of male game players in Indonesia aged 10 to 20 years old is $62 \%$. These descriptions strengthen the statement saying that the number of male gamers in Indonesia is more than female players.

Looking back the data of gamers' age in Indonesia, it is categorised into a productive age. It is shown by the respondents' ages ranging from 15 to 25 years old. Statistics Center Agency (BPS) defines a group of productive age is those who are in the range of 15-64 years old. This study reveals that most respondents are highly experienced gamers. It can be seen from the experience and the intensity in playing game. In this study, most respondents $(80 \%)$ are gamers who have many experiences in playing game. The respondents involved have at least 2-year experience of playing the game. Besides, it is also known that their intensity in playing games is 4 hours per day in average for 2 years. The hypothesis testing was conducted to assess the relation between research variables by seeing the significance value (P). This study used trust level of $95 \%$, so that a relation can be stated significant if the value of $P$ is less than 0.05 and the value of critical ratio (CR) is more than 2. Based on the result of test with SEM by using AMOS software, it is known that from five hypotheses proposed, there are three hypotheses accepted and two hypotheses rejected. Consumer flow influences attitude towards mobile advergame significantly; it can be seen from the number of CR of 2.025 and probability value of 0.024 , which is less than 0.05 . However, consumer flow does not give an influence significantly on attitude towards brand; it can be seen from the value of CR which is below 2, it is 1.937 and the value of probability is more than 0.5 . Attitude towards mobile advergame gives significant influence on attitude towards brand; it can be seen from the value of $\mathrm{CR}$ which is more than 2 , that is 2.126 with the probability value of 0.021 . Competitor traits strengthen the influence of consumer flow on attitude towards mobile advergame. It can be seen from the value of CR of 2.567 and the value of probability which is less than 0.13 . In contrast, competitor traits does not influence causal relation between consumer flow and attitude towards brand which can be seen from the value of $\mathrm{CR}$ which is less than 2, that is 1.688 and the probability value of 0.602 . 
Table 4 Results of the hypothesis testing

\begin{tabular}{lccc}
\hline Relationships between variables & Estimate & CR & Probability \\
\hline Flow $\rightarrow$ Attitude towards advergame & 0.564 & 2.025 & 0.024 \\
Flow $\rightarrow$ Attitude towards brand & 0.345 & 1.937 & 0.053 \\
Attitude towards advergame $\rightarrow$ Attitude towards brand & 0.567 & 2.126 & 0.021 \\
Competitor traits $\rightarrow$ Attitude towards advergame & 0.621 & 2.373 & 0.019 \\
Competitor traits $\rightarrow$ Attitude towards brand & 0.599 & 2.459 & 0.018 \\
Competitor traits *Flow $\rightarrow$ Attitude towards advergame & 0.671 & 2.567 & 0.013 \\
Competitor traits*Flow $\rightarrow$ Attitude towards brand & 0.256 & 1.688 & 0.602 \\
\hline
\end{tabular}

The relationship between variable of flow and attitude towards mobile advergame is noticed. It makes that the consumer's flow gives effect on attitudes towards mobile advergame. It indicates that the more flow perceived on the game, the more positive response to the mobile advergame. The result of the study is in line with the study conducted by Waiguny's et al. (2011). The study suggests that consumer flow has a significant positive impact on attitude towards the game.

The relationship between attitude towards mobile advergame and attitude towards the brand has CR score of 2.126 and probability level of 0.021 . It means that attitude towards mobile advergame has a significant effect on attitude towards brand. The more positive attitude on mobile advergame, the more positive attitude on everything attached to the mobile advergame, including the brand that is displayed to the mobile advergame. It is in accordance with Schiffman and Kanuk (2010) stating that exposure of advertising will affect the attitude towards advertising and ultimately will give impact on attitude towards brand.

The result of the study shows that competitor traits is positive significance as the moderating variable for the relationship between consumer flow and attitude towards mobile advergame. Competitor trait plays an important role in game player's behaviour like attitude towards mobile advergame. The relationship between competitor traits and attitude towards mobile advergame has CR score of 2.567 and probability of 0.013 . Competitor trait reinforces the influence of consumer flow on attitude towards the mobile advergame. The results of this study indicate that the person who likes challenge and competition will strengthen the influence of consumer's flow on attitude towards mobile advergame. It is in accordance with Schiffman and Kanuk (2010) postulating that consumer characteristics include demographic, psychological and social characteristics determine consumer behaviour. The result of the study is also similar to Vorderer and Bryant (2012) that distinguish the characteristics of game players in nine types. Competitor trait as the most common type of game player is liking the challenges and competition. Consumer flow gives an influence on the attitude towards the mobile advergame. The feeling of this flow will be stronger if the game player likes challenges and competitions. Thus, the influence of flow on attitude towards mobile advergame will be greater. The competitor trait will strengthen the influence of the flow on attitude towards mobile advergame.

The game players focus on the game being played proven by the significant influence of flow on the attitude towards mobile advergame. However, this study shows that consumer's flow feelings do not give impact the attitude towards brands exposed to game players. This suggests that game players are totally unaware of the products or brands 
exposed on the mobile advergame. They focus on the game itself. They do not think or do not consider the attributes that are exposed in the mobile advergame. The most important thing for game players is the challenging game to play; they do not mind about who created the game, or what the game is based on. Game player only focuses on the game in the mobile advergame.

Consumer flow does not have significant influence on attitude towards brand. This result indicates that game player does not pay attention on existing brands on the mobile advergame. They focus on playing a role in the mobile advergame. He is aware of the brand, but not to the extent of responding to the brand. Thus, because the main effect of consumer flow does not have significant influence on attitude towards the brand, so that the competitor traits do not moderate the relationships of consumer flow on the attitude towards the brand. This is because whatever the characteristics of the game players, either the competitor trait is high or low, the game player has already had a high flow experience. In other words, competitor trait will not increase the role of consumers' flow on the attitude towards the brand. The game player focuses on the attention on the mobile advergame, regardless of exposed brands, so that competitor trait does not moderate the influence of consumers' flow on attitudes towards brands.

\section{Result and future research}

The research result reveals that there are five hypotheses: three hypotheses are accepted and two hypotheses are rejected. Consumer flow influences attitude towards mobile advergame significantly; the higher the consumer flow in playing mobile advergame, the more positive their attitude on the mobile advergame. Attitude towards mobile advergame gives a significant influence on attitude towards brand. The more positive the attitude towards mobile advergame, the more positive the attitude towards brand will be. It can be concluded that to make a positive attitude towards brand, the marketers must enhance attitude towards the mobile advergame. The result of this study proves that consumer flow has a vital role to make a positive attitude towards game. Therefore, it is important for the marketers to enhance consumer flow. It can be done by improving a role-model character and story content in the mobile advergame to be more challenging.

Consumer flow does not influence attitude towards brand significantly. It is possible because the respondents (gamers) focus on playing the role model in the mobile advergame. The mobile advergame only makes the consumers aware of the existing brand, but not make a positive attitude towards the brand.

The influence of consumer flow on attitude towards mobile advergame is moderated by the characteristics of gamers (in this study, it is competitor trait). The influence of consumer flow on attitude towards mobile advergame is determined by the individual characteristics (in this study, it is competitor trait). The influence of consumer flow on attitude towards mobile advergame will be stronger when the respondents (gamers) have high competitor traits. It is because the mobile advergame genre used in this study is adventure. The more gamers involved in the mobile advergame and they have high competitor traits, the more positive the attitude towards the mobile advergame will be. It shows that gamers involving in the mobile advergame and having congruent characteristics with the game genre will have positive attitude on the mobile advergame. 
Consumer flow does not influence attitude towards brand. Probably, it is because the consumers (gamers) focus more on the role played in the mobile advergame. The mobile advergame makes them able to know the brand, not until determine the attitude on brand. The further research is needed to explain this phenomenon of inserting variables of other individual characteristics like social aspect, namely, lifestyle; demographic aspect like education, income, occupation and gender; and psychological aspect like personality, believed values such as religion and nationalism.

This research focuses on adventure genre. The future research is essential to be applied on other genre like Action, RPG, simulation, strategy and sport. This genre selection should be in line between the individual characteristics from target market and the product offered by the company.

\section{References}

Aggarwal, A. and Arora, N. (2019) 'Gamification and advergaming: an overview of the innovative brain tool in the field of advertising', Application of Gaming in New Media Marketing, IGI Global, pp.23-35.

Blackwell, R.D., Miniard P.W. and Engel, J.F. (2006) Consumer Behavior, 10th ed., Thomson Learning.

Cauberghe, V. and De Pelsmacker, P. (2010) 'Advergames', Journal of Advertising, Vol. 39, No. 1, pp.5-18.

Csikszentmihalyi, M. (1990) The Psychology of Optimal Experience, Harper \& Row Publishers, New York.

Goh, K.Y. and Ping, J.W. (2014) 'Engaging consumers with advergames: an experimental evaluation of interactivity, fit and expectancy', Journal of the Association for Information Systems, Vol. 15, No. 7, p.388.

Gura, S. and Gura, K. (2016) 'The use of mobile advergame as brand communication tool: case study "Vodafon City"', American Journal of Marketing Research, Vol. 2, No. 2, pp.61-72.

Gurau, C. (2008) 'The influence of advergames on players' behaviour: an experimental study', Electronic Markets, Vol. 18, No. 2, pp.106-116.

Hausman, A.V. and Siekpe, J.S. (2009) 'The effect of web interface features on consumer online purchase intentions', Journal of Business Research, Vol. 62, No. 1, pp.5-13.

Hawkins, D. and Mothersbaugh, D. (2012) Consumer Behavior: Building Marketing Strategy, 12th ed., McGraw-Hill Education.

Hernandez, M.D. (2008) 'Determinants of children's attitudes towards "advergames": the case of Mexico', Young Consumers, Vol. 9, No. 2, pp.112-120.

Hernandez, M.D. (2011) 'A model of flow experience as determinant of positive attitudes toward online advergames', Journals of Promotions Management, Vol. 17, No. 3, pp.315-326.

Hoffman, D.L. and Novak, T.P. (1996) 'Marketing in hypermedia computer-mediated environments conceptual foundations', Journal of Marketing, Vol. 60, pp.50-68.

Holbrook, M.B., Chestnut, R.W., Oliva, T.A. and Greenleaf, E.A. (1984) 'Play as a consumption experience: the roles of emotions, performance, and personality in the enjoyment of games', Journal of Consumer Research, Vol. 11, No. 2, pp.728-739.

Hopp, T. and Barker, V. (2016) 'Investigating the influence of age, social capital affinity, and flow on positive outcomes reported by e-commerce site users', Behaviour \& Information Technology, Vol. 35, No. 5, pp.380-393.

Hu, X.Y., Khoo, B.C., Adams, N.A. and Huang, F.L. (2006) 'A conservative interface method for compressible flows', Journal of Computational Physics, Vol. 219, No. 2, pp.553-578. 
Huang, H.C., Pham, T.T.L., Wong, M.K., Chiu, H.Y., Yang, Y.H. and Teng, C.I. (2018) 'How to create flow experience in exergames? Perspective of flow theory', Telematics and Informatics, Vol. 35, No. 5, pp.1288-1296.

Kotler, P. and Keller, K.L. (2016) Marketing Management, 15th ed., Pearson, UK.

Koufaris, M. (2002) 'Applying the technology acceptance model and flow theory to online consumer behavior', Information System Research, Vol. 13, No. 2, pp.205-223.

Laskowska-Witek, J. and Mitręga, M. (2014) 'Brand promotion through computer games on the example of second life', StudiaEkonomiczne, Vol. 205, pp.34-48.

Laudon, K.C. and Traver, C.G. (2016) E-Commerce: Business, Technology, Society.

LIPI (11 March 2016) Having many productive age, Indonesia expect to boost productivity. Available online at: http://lipi.go.id/berita/jumlah-usia-produktif-besar-indonesia-berpeluangtingkatkan-produktivitas/15220 (accessed on 20 January 2019)

Lu, S., Au, W.T., Jiang, F., Xie, X. and Yam, P. (2013) 'Cooperativeness and competitiveness as two distinct constructs: validating the cooperative and competitive personality scale in a social dilemma context', International Journal of Psychology, Vol. 48, No. 6, pp.1135-1147.

Mathwick, C. and Rigdon, E. (2004) 'Play, flow, and the online search experience', Journal of Consumer Research, Vol. 31, pp.324-332.

Mowen, J.C. and Minor, M.S. (2001) Consumer Behavior (A Framework), Prentice Hall.

Newzoo (2017) The Indonesian gamer | 2017. Available online at: https://newzoo.com/insights/ infographics/the-indonesian-gamer-2017 (accessed on 20 January 2019)

Novak, T.P., Hoffman, D.L. and Yung, Y.F. (2000) 'Measuring the customer experience in online environments: a structural modeling approach', Marketing Science, Vol. 19, No. 1, pp.22-42.

Nusair, K. and Parsa, H.G. (2011) 'Introducing flow theory to explain the interactive online shopping experience in a travel context', International Journal of Hospitality \& Tourism Administration, Vol. 12, pp.1-20.

Peter, J.P. and Olson, J.C. (2008) Consumer Behaviour and Marketing Strategy, 8th ed., McGrawHill Companies Inc., New York.

Schiffman, L.G. and Kanuk, L.L. (2010) Consumer Behaviour, 10th ed., Pearson Prentice Hall, New Jersey.

Sherry, J.L. (2004) 'Flow and media enjoyment'. Communication Theory, Vol. 14, No. 4, pp.328-347.

Shimps, T.A. and Andrews, J.C. (2013) Advertising Promotion and Other Aspects of Integrated Marketing Communications, 9th ed., SouthWestern, USA.

Sofi, S.A., Nika, F.A., Shah, M.S. and Zarger, A.S. (2018) 'Impact of subliminal advertising on consumer buying behaviour: an empirical study on young Indian consumers', Global Business Review, Vol. 19, No. 6, pp.1580-1601.

Solimun, N. and Rinaldo, A.A. (2006) PermodelanPersamaanStrukturalPendekatan PLS dan SEM. ModulPelatihanAplikasi Software Smart PLS dan AMOS, Fakultas MIPA dan Program Pascasarjana, Universitas Brawijaya Malang.

Sreejesh, S., Anusree, M.R. and Ponnam, A. (2018) 'Does game rules work as a game changer? Analyzing the effect of rule orientation on brand attention and memory in advergames', Computers in Human Behavior, Vol. 81, pp.325-339.

Strauss, J. and Frost, R.D. (2016) E-Marketing: Instructor's Review Copy, Routledge.

Turban, E., Outland, J., King, D., Lee, J.K., Liang, T.P. and Turban, D.C. (2017) Electronic Commerce 2018: A Managerial and Social Networks Perspective, Springer.

Turban, E., Outland, J., King, D., Lee, J.K., Liang, T.P. and Turban, D.C. (2018) 'Mobile commerce and the internet of things', Electronic Commerce 2018, Springer, Cham, pp.205-248.

Vanwesenbeeck, I., Ponnet, K. and Walrave, M. (2016) 'Go with the flow: how children's persuasion knowledge is associated with their state of flow and emotions during advergame play', Journal of Consumer Behaviour, Vol. 15, No. 1, pp.38-47. 
Van Reijmersdal, E.A., Rozendaal, E. and Buijzen, M. (2012) 'Effects of prominence, involvement, and persuasion knowledge on children's cognitive and affective responses to advergames', Journal of Interactive Marketing, Vol. 26, No. 1, pp.33-42.

Vashisht, D. and S. Pillai, S. (2017) 'Are you able to recall the brand? The impact of brand prominence, game involvement and persuasion knowledge in online-advergames', Journal of Product \& Brand Management, Vol. 26, No. 4, pp.402-414.

Vorderer, P. and Bryant, J. (2012) Playing Video Games: Motives, Responses, and Consequences, Routledge.

Waiguny, M.K., Nelson, M.R. and Terlutter, R. (2012) 'Entertainment matters! The relationship between challenge and persuasiveness of an advergame for children', Journal of Marketing Communications, Vol. 18, No. 1, pp.69-89.

Waiguny, M.K., Terlutter, R. and Zaglia, M.E. (2011) 'The influence of advergames on consumers' attitudes and behaviour: an empirical study among young consumers', International Journal of Entrepreneurial Venturing, Vol. 3, No. 3, pp.231-247.

Weber, R., Tamborini, R., Wescott-Baker, A. and Kantor, B. (2009) 'Theorizing flow and media enjoyment as cognitive synchronization of attentional and reward network', Communication Theory, Vol. 19, pp.397-422.

Wu, I.L., Chen, K.W. and Chiu, M.L. (2016) 'Defining key drivers of online impulse purchasing: a perspective of both impulse shopper and system users', International Journal of Information Management, Vol. 36, pp.284-296.

Wu, P.C. and Wang, Y.C. (2011) 'The influences of electronic word-of-mouth message appeal and message source credibility on brand attitude', Asia Pacific Journal of Marketing and Logistics, Vol. 23, No. 4, pp.448-472. 